\title{
EVDE SAĞLIK HASTALARINDA D VITAMINİ DÜZEYLERİ
}

\author{
Vitamin D Levels in Home Healthcare Patients
}

\section{Erdal DİLEKÇí1, Esra ADEMOĞLU DİLEKÇİ², Muhammed Emin DEMİRKOL ${ }^{3}$, Muhammed Nur ÖGÜN ${ }^{4}$}

\author{
${ }^{1}$ Abant Izzet Baysal Üniversitesi, Fiziksel Tip ve Rehabilitasyon EAH, FTR A.D., BOLU, TÜRKIYYE \\ ${ }^{2}$ Abant İzzet Baysal Üniversitesi Tıp Fakültesi, İç Hastalıklarl A.D., Endokrinoloji ve Metab. Hast., BOLU, TÜRKIYYE \\ ${ }^{3}$ Abant İzet Baysal Devlet Hastanesi, Iç Hastalıkları A.D., BOLU, TÜRKIYE \\ ${ }^{4}$ Abant İzet Baysal Üniversitesi Tip Fakültesi, Nöroloji A.D., BOLU, TÜRKIYYE
}

Amaç: $\mathrm{Bu}$ çalışmada mobilize olamayan, güneş 1şı̆̆ından faydalanamayan ve malnütrisyonun sık görüldüğü evde sağlık hastalarında, serum albümin ve 25 -hidroksi $D(25[\mathrm{OH}] \mathrm{D})$ vitamini düzeylerini incelenmeyi amaçladık.

Gereç ve Yöntem: Bu çalışmaya Ocak 2017 ve Temmuz 2017 tarihleri arasında Bolu ilinde evde sağlık hizmetleri tarafından takipli, evden dışarıya çıkamayan ve tümü aile bireyleri tarafindan bakılan yatağa bağımlı 57 evde bakım hastası dahil edildi. Kontrol grubu HBYS'de kayıtlı 42 sağlıklı bireyden oluşturuldu. Kişilerin demografik verileri ve kan değerleri takip dosyalarından retrospektif olarak elde edildi. Tüm hastalarda ve kontrol grubunda serum $25(\mathrm{OH}) \mathrm{D}$, kalsiyum ve albümin düzeyleri incelendi.

Bulgular: Evde sağlık hastalarının yaş ortalaması $77.7 \pm 14.01$ yıl, kontrol grubunun yaş ortalaması $74.2 \pm 17.03$ yıl idi. Serum $25(\mathrm{OH}) \mathrm{D}$ düzeyleri hasta grubunda $11.77 \pm 9.07 \mathrm{ng} / \mathrm{dL}$, kontrol grubunda $22.62 \pm 7.41 \mathrm{ng} / \mathrm{dL}$ idi $(\mathrm{p}<0.001)$. Serum kalsiyum ve albümin düzeyleri hasta grubunda kontrol grubuna göre istatistiksel olarak anlamlı derecede daha düşüktü $(\mathrm{p}<0.001)$.

Sonuç: Evde sağlık hizmeti kapsamında takip edilen hastalar malnütrisyon ve D vitamini eksikliği açısından risk altında olup hastaların bu açıdan takibi ve tedavisi önem teşkil etmektedir. Bu konudaki bulgularımızı doğrulamak için ileri çalışmalara ihtiyaç vardır.

Anahtar Kelimeler: Evde sağllk hizmeti, vitamin D, albümin, beslenme
Objective: In this study, we aimed to investigate serum levels of albumin and 25-hydroxyvitamin D (25[OH]D) in home healthcare patients who were immobilized, had lack of sun exposure, and were frequently malnourished.

Material and Methods: Fifty-seven bedridden patients who were being cared by family members, and followed by home health care services in Bolu between January 2017 and July 2017 were included in this study. Control group was composed of 42 healthy individuals registered in HBYS (Hospital İnformation Manegement System). Demographic characteristics and blood values of individuals were obtained retrospectively from medical records. Serum $25(\mathrm{OH}) \mathrm{D}$, calcium and albumin levels were examined in all patients and control group.

Results: The mean age was $77.7 \pm 14.01$ years in home healthcare patients and $74.2 \pm 17.03$ years in the control group. Serum $25(\mathrm{OH}) \mathrm{D}$ levels were determined as $11.77 \pm 9.07 \mathrm{ng} / \mathrm{dL}$ in home healthcare patients and $22.62 \pm 7.41 \mathrm{ng} / \mathrm{dL}$ in the control group $(p<0.001)$. Serum calcium and albumin levels were statistically significantly lower in the patient group than in the control group.

Conclusion: Patients who are being followed by home health care services are at risk for developing Vitamin D deficiency and malnutrition. Therefore it is important to follow up and treat such patients. Larger sample size and better designed prospective studies are needed to confirm our findings for this healtcare problem.

Keywords: Home healthcare, vitamin D, albumin, nutrition 


\section{GíRiş}

Evde sağlık kavramı; koruyucu, tedavi ve rehabilite edici sağlık bakımı sürekliliğinin etkili biçimde sürdürülmesi amacını güden, birey ve aileye yaşadığı ortamda sunulan sağlık bakım hizmetleri yaklaşımıdır (1). Evde sağlık hizmeti (ESH); alan bireyin yaşamını etkileyen hastalık durumunun, günlük yaşam aktivitelerine etkisini en aza indirilerek k1sa sürede en yüksek düzeyde fonksiyon görme becerisine, bağımsızlığına ulaşmasını ve yaşam kalitesinin artırılmasını amaçlayan hizmettir (2). T.C. Sağlık Bakanlığg, evde sağlık hizmetini çeşitli hastalıklara bağlı olarak evde sağlık hizmeti sunumuna ihtiyacı olan bireylere evinde ve aile ortamında sosyal ve psikolojik danışmanlık hizmetlerini de kapsayacak şekilde verilen muayene, tetkik, tahlil, tedavi, tıbbi bakım, takip ve rehabilitasyon hizmetleri olarak tanımlamış ve 2010 yılında yayınladığı yönerge ile sosyal devlet politikası kapsamında hizmet sunumuna başlamıştır. ESH kapsamındaki hastalar genellikle geriatrik yaş grubunda olup multipl komorbid hastalığa sahip, fiziksel olarak bağımlı kişilerdir. Geriatrik yaş grubunda malnütrisyon ciddi bir problemdir $(3,4)$. Yaşlılarda en sık malnütrisyon tipi enerji-protein azlığı ve buna bağlı yetersiz beslenmedir (5). Çoğu zaman malnütrisyon sinsi başlar ve fark edilmez (6). Yara iyileşmesi, fibroblast proliferasyonu, anjiogenez, yeterli bağışıklık yanıtının oluşması ve kollojen sentezi için yeterli protein alımı gereklidir $(7,8)$. Yaşlıda beslenme durumunun saptanmasında kullanılabilecek parametreler; antropometrik ölçümler, laboratuvar değerlendirmeleri, klinik değerlendirme ve diyet içeriğinin değerlendirilmesidir. Laboratuvar parametrelerinden en çok albümin kullanılmakla birlikte duyarlılığı ve seçiciliği düşük olup malnütrisyonu gösteren kesin bir laboratuvar belirteci yoktur (9).

D vitamininin vücutta en önemli etkisi kalsiyum homeostazı ve kemik metabolizması üzerine olmakla birlikte son y1llarda anti-proliferatif, pro-diferansiyatif, pro-apoptotik ve immunomodülatör fonksiyonlarını açıklayan birçok çalışma mevcuttur (10-13). D vitamininin deride sentezlenen kolekalsiferol (vitamin $\mathrm{D}_{3}$ ) ve besinlerle alınan ergokalsiferol (vitamin $\mathrm{D}_{2}$ ) olmak üzere iki kaynağı vardır. Normal koşullarda insan vücudunda bulunan D vitamininin \%90-95'i güneş ışınlarının etkisi ile deride yapılır (Şekil 1) (12). Kişideki vitamin D düzeyini değerlendirmek için yarı ömrü 2-3 hafta olan hem endojen yapımı hem de eksojen kaynaklı alımı gösteren 25(OH)D düzeyi bakılmalıdır $(14,15)$.

$\mathrm{Bu}$ çalışma, evde sağlık hizmetleri kapsamında takip edilen hastaların beslenme durumları ve vitamin D düzeyleri hakkında bilgi edinmek amacıyla yapılmıştır.

\section{GEREÇ VE YÖNTEM}

Bu çalışmada Ocak 2017 ve Temmuz 2017 tarihleri arasında Bolu ilinde İzzet Baysal Devlet Hastanesi Evde Sağlık Hizmetleri birimi tarafından takipli, en az bir yıldır yatağa bağımlı veya en az bir kişinin desteği ile ev içi kısmi mobilize olan, oral yoldan beslenen 57 olgu ile Hastane Bilgi Yönetim Sistemi (HBYS)'de kayıtlı 42 sağlıklı birey dâhil edilmiştir. Kontrol grubunu oluşturan sağlıklı bireylerin hiçbirinde diyabet, ilaç kullanımı, kronik karaciğer hastalığı, inflamatuvar barsak hastalığı, kardiyovasküler hastalık, kronik böbrek hastalığı, akut veya kronik inflamatuvar hastalık öyküsü yoktu. Fiziksel aktivitesine göre tüm gününü yatakta geçiren hastalar yatağa bağımlı olarak değerlendirildi. Hastaların tümü beslenme defektleri açısından risk taşıyan ve güneş ışığı ile teması olmayan bireylerdi. $\mathrm{Bu}$ hastaların tümünün bakımları aile bireyleri tarafından yapılmaktaydı. Yatağa bağıml olup nazogastrik sonda ve PEG ile beslenen hastalar çalışma dışında bırakıldı. Kişilerin demografik bilgileri toplandıktan sonra kan değerleri takip dosyalarından retrospektif olarak elde edildi. Tüm hastaların serum 25 $(\mathrm{OH}) \mathrm{D}$, kalsiyum ve albümin düzeyleri incelendi. Mükerrer tetkik sonucu bulunan hasta değerlerinden en son tarihte bakılan değer çalışmaya dâhil edildi. 


\section{İstatistiksel Analiz}

Verilerin analizi Statistical Package for Social Science (SPSS 15.0) programı kullanılarak yapıldı. Verilerin normal dağılım gösterip göstermediği Shapiro-Wilk's testi ile değerlendirildi. Tüm sürekli değişkenler ortalama \pm standart sapma olarak gösterildi. Gruplar arasında ortalamalar yönünden farkın önemliliği Student's T testi ile değerlendirildi. $\mathrm{p}<0.05$ değeri istatistiksel anlamlılık düzeyi olarak kabul edildi.

\section{BULGULAR}

Evde sağlık hastalarının yaş ortalaması $77.7 \pm 14.01$ y1l, kontrol grubunun $74.2 \pm 12.03$ y1l idi. İki grupta da yaş ortalaması benzer olup geriatrik hasta grubunda değerlendirildi. Evde sağlık hastalarının 25(OH)D düzeyi $11.77 \pm 9.07 \mathrm{ng} / \mathrm{mL}$, serum kalsiyum düzeyi $8.61 \pm 0.66 \mathrm{mg} / \mathrm{dL}$ idi ve kontrol grubuna göre istatistiksel olarak anlamlı şekilde düşüktü $(p<0.001)$. Benzer şekilde evde sağlık hizmeti alan hastaların serum albümin seviyeleri $3.66 \pm 0.64$ idi ve kontrol grubuna göre istatistiksel olarak anlamlı şekilde $(\mathrm{p}<0.001)$ düşüktü. Verilerin karşılaştırılması Tablo 1 'de verilmiştir.

Tablo 1. Çalışmaya alınan olgu gruplarının demografik ve laboratuvar karakteristikleri

\begin{tabular}{lccc}
\hline Parametre & $\begin{array}{c}\text { Kontrol grubu } \\
(\mathbf{n = 4 2})\end{array}$ & $\begin{array}{c}\text { ESH } \\
(\mathbf{n = 5 7})\end{array}$ & $\mathbf{p}$ \\
\hline $\mathbf{2 5}(\mathbf{O H}) \mathbf{D}(\mathbf{n g} / \mathbf{m L})$ & $22.62 \pm 7.41$ & $11.77 \pm 9.07$ & $<0.001$ \\
Serum Kalsiyum (mg/dL) & $9.28 \pm 0.48$ & $8.61 \pm 0.66$ & $<0.001$ \\
Serum Albümin (g/dL) & $4.3 \pm 0.35$ & $3.66 \pm 0.64$ & $<0.001$ \\
\hline
\end{tabular}

ESH: Evde sağlık hizmeti alan hastalar

\section{TARTIŞMA}

Geriatrik yaş grubunda malnütrisyon göz önünde bulundurulması gereken ve ciddi komplikasyonlara neden olan bir problemdir. Yağsız vücut kitlesi azalmakta, yăg dokusu artmakta, bazal metabolik hız azalmaktadır. Böylece yaşlandıkça kalori ihtiyacı azalırken, protein ve bazı mikronütrientlerin (kalsiyum, vitamin D, B12, folat vb.) ihtiyac1 artmaktadır. Bununla beraber ağız ve diş problemlerinin varlı̆̆ gastrointestinal ve üriner sistemde görülen sorunlar, tat ve koku duyusunda bozulma ve fiziksel bağımlılık ta malnütrisyon un diğer nedenleri içindedir $(3,4)$. ESH kapsamındaki hastalar genellikle geriatrik yaş grubunda olup multipl komorbid hastalığa sahip, fiziksel olarak bağımlı kişilerdir. Hisar ve arkadaşlarının çalışmasında yaş ortalaması $74 \pm 15.4$ yıl olarak saptanmıştır (1). Bizim çalışmamızda da benzer şekilde yaş ortalamasını $77.7 \pm 14.01$ yıl olarak saptadik.
Yaşlılarda en sık malnütrisyon tipi enerji-protein azlığı ve buna bağlı yetersiz beslenmedir (5). Çoğu zaman malnütrisyon sinsi başlar ve fark edilmez (6). Malnütrisyonu saptamak için en çok kullanılan antropometrik ölçüt beden kitle indeksi (BKİ) olmakla birlikte yağ dokusu ile kas dokusunu kayıplarını ve santral obeziteyi ayırt etmez. Laboratuvar parametrelerinden en çok albümin kullanılmakla birlikte duyarlılığı ve seçiciliği düşük olup malnütrisyonu gösteren kesin bir laboratuvar belirteci yoktur. Günlük beslenme içeriği kaydı değerli olmakla beraber doğru kayıt alınması ve uygulanması güçtür (9). Ayrica Avrupa beslenme taranması rehberleri yaşlılarda Mini Nutrisyonel Değerlendirme (MNA) veya Mini Nutrisyonel Değerlendirme Kısa Form (MNA-SF) önermektedir (16). Christensson ve arkadaşları MNA'nın malnütrisyonun erken saptanması ve önlenmesi için kullanışlı bir ölçüt olduğunu, malnütrisyonun başladığı hastalarda MNA ile beraber 
antropometrik ölçümler ve serum proteinlerinde belirgin düşüklük saptamıştır (17). Çevik ve arkadaşları 178 hasta ile yapmış olduğu çalışmada MNA sınıflamasına göre malnütrisyon düzeyi derinleştikçe serum albümin ve protein değerlerinde azalma olduğu, ancak malnütrisyonun erken dönemlerinde bu azalmanın anlamlı şekilde görülmediği ve özellikle erken müdahale ile önlenebilecek malnütrisyon larda serum albümin ve protein değerlerinin önemli olmadığını iddia etmişlerdir (18). Çalışmamızda serum albümin miktarlarını kontrol grubuna göre istatistiksel olarak anlamlı düşük saptadık. $\mathrm{Bu}$ sonuç, hastalarımızın geriatrik yaş grubundan oluşması ve bir yıldan uzun süredir yatağa bağımlı olmalarından dolayı malnütrisyon tehlikesi altında olduklarını ortaya koymuştur. Akan ve arkadaşlarının yaptıkları bir çalışmada malnütrisyon ve malnütrisyon riskinin yaş ve cinsiyetle ilgili olmadığı, ancak yatağa bağımlılık, hipertansiyon ve/veya koroner kalp yetmezliği, bası yarası varlığında arttığı ortaya konmuştur (19).

Kişideki vitamin D düzeyini değerlendirmek için yarı ömrü 2-3 hafta olan hem endojen yapımı hem de eksojen kaynaklı alımı gösteren 25(OH)D düzeyine bakılmalıdır. Biyolojik aktif form 1,25(OH) $\mathrm{D}_{2}$ ideal ölçüm için uygun değildir. Çünkü yarı ömrü 4-6 saat kısa ve dolaşımdaki düzeyleri 25(OH)D'den 1000 kat daha düşüktür. 25(OH)D $30 \mathrm{ng} / \mathrm{mL}$ 'den yüksek ise yeterli düzey kabul edilmekle beraber tercih edilen değer 40-60 ng/mL'dir (14,15). Özkan ve arkadaşları Rikets ve Osteomalazi gibi hastalıkların önlenmesi ve normal kemik kalitesinin idamesi için serum 25(OH)D düzeyi 20 ng/mL'nin üzerinde olmasını önermekle beraber kanser, otoimmün hastalıklar ve kardiyovasküler hastalıklar gibi kronik hastalık riskini azaltmak için bu değerin $30 \mathrm{ng} / \mathrm{dL}$ 'nin üzerinde olması gerektiğini belirtmişlerdir. Bu değerler için günde 800$1000 \mathrm{U}$ vitamin D takviyesi alınması önerilmektedir (12). Çalışmamızda serum 25(OH)D ve kalsiyum düzeylerini kontrol grubuna göre istatistiksel olarak anlamlı derece düşük saptadık. Literatürde evde sağlık hizmeti alan hastalarda vitamin D düzeyi ile ilgili az sayıda çalışma mevcuttur. Akpınar ve arkadaşlarının bir çalışmasında vitamin D eksikliğinin ağrı, yaşam kalitesi, proksimal kas güçsüzlüğü ve nöromuskuler koordinasyon bozukluğu ve düşmeye yatkınlıkla ilgili olduğu ortaya konmuştur. Ayrıca, ev içinde uzun süre geçirme, kapalı giyim, yüksek faktörlü güneş koruyucu kullanımı ve yüksek rakımda yaşamanın da vitamin D yetersizliğine predispoze faktörler olduğu belirtilmiştir (20). Evde sağlık hizmeti alan hastalarda yüksek malnütrisyon riski, yatağa bağımlılık ve güneş 1şı̆̆ maruziyetinin de kısıtlılık gibi nedenlerle vitamin D eksikliği ve yetersizliği sık görülmekte olup, hastaların bu açıdan yakın takibi önem arz etmektedir.

Çalışmamızın sınırlılıkları; hasta sayımızın sınırlı olması, retrospektif olması dolayısıyla verilerin k1sıtlı olması, antropometrik ölçüm ve günlük beslenme içeriği kaydı gibi objektif değerlendirme materyallerinin olmamasidir.

Sonuç olarak literatürde ESH kapsamında takip edilen hastaların malnütrisyon ve vitamin $D$ ile ilgili laboratuvar değerleri, beslenme miktarı ve klinik durumunu beraberce değerlendiren çalışmaların çok kısıtlı sayıda olduğunu gözlemledik. Yaptığımız çalışma ve literatür taraması sonrasında ESH'nin dünyada ve Türkiye'de yeni bir kavram olduğu, takip edilen hastaların özellikle malnütrisyon varlığı ve vitamin D düzeyleri ile mikronütrient takiplerinin, erken tanı ve erken replasmanın önemli olduğunu saptadık. Ancak bulgularımızın doğruluğunu pekiştirmek için, daha ileri çalışmalara ihtiyaç vardır.

Çıkar Çatışması: Yoktur.

\section{KAYNAKLAR}

1. Hisar KM, Erdoğdu H. Evde sağlık hizmeti alanlarda yaşam kalitesi durumu ve etkileyen faktörlerin belirlenmesi. Genel Tıp Dergisi. 2014; 24: $138-42$.

2. Akdemir N, Bostanoğlu H, Yurtsever S, Kutlutürkan S, Kapucu S, Canlı Özer Z. Yatağa bağımlı hastaların evde yaşadıkları sağlık sorunlarına yönelik evde bakım hizmet 
gereksinimleri. Dicle T1p Dergisi. 2011; 38(1): 5765.

3. Visvanathan R. Undernutrition in older people: A serious and growing global problem. J Postgrad Med. 2003; 49(4): 352-60.

4. Yeh SS, Schuster MW. Treatment of cachexia in the elderly. In: Mantovani G, Anker SD, Inui A, Morley JE, Fanelli FR, Scevola D, et al, editors. Cachexia and wasting: a modern approach. link.springer.com. Milan: Springer; 2006: 701-17.

5. Mucci E, Jackson SHD. Nutritional suplementation in community-dwelling elderly people. Ann Nutr Metab. 2008; 52: 33-7.

6. Nutrition Screening Initiative. Nutrition statement of principle. Chicago: American Dietetic Institution and the American Academy of Family Physician; 2002.

http://www.eatright.org/ada/files/nutrition(1).pdf. Erişim tarihi: 06.10.2017.

7. Jeffrey AN, Eastman SM. The effective management of pressure ulcers. Advances in Skin\&Wound Care. 2006; 19(1): 3-15.

8. Litchfor M, Dorner B, Posthauer M. Malnutrition as a precursor of pressure ulcers. ADV Wound Care. 2014; 3(1): 54-63.

9. Johnson LE, Sullivan DE. Nutrition and failure to thrive. In: Landefeld CS, Palmer RM, Johnson MA, Johnston CB, Lyons WL editors. Current geriatric treatment and diagnosis. International ed. Mc Graw Hill Companies. New York. 2004: 391-406.

10. Vogeser M. Quantification of circulating 25hydroxyvitamin $\mathrm{D}$ by liquid chromatographytandem mass spectrometry. Journal of steroid Biochemistry\&Molecular Biology 2010; 121: 56573.

11. May FM, Bulgiba A. High prevalence of vitamin D insufficiency and its association with obesity and metabolic syndrome among Malay adults in Kuala Lumpur, Malaysia. Public Health. 2011; 11: 735.

12. Özkan B, Döneray H. D vitamininin iskelet sistemi dışı etkileri. Çocuk Sağlığı ve Hastalıkları Dergisi. 2011; 54: 99-119.
13. Holick MF. Vitamin D: a D-lightful health perspective. Nutr Rev. 2008; 66: 182-94.

14. Wacker M, Holick MF. Vitamin D-Effects on Skeletal and Extraskeletal Health and the Need for Supplementation. Nutrients. 2013; 5: 111-48.

15. Holick MF, Binkley NC, Bischoff-Ferrari HA, et al. Evaluation, Treatment and Prevention of Vitamin D Deficiency: an Endocrine Society Clinical Practice Guideline. J Clin Endocrinol Metab. 2011; 96: 1911-30.

16. Guigoz Y, Vellas B, Garry BJ. The Mini Nutritional Assessment (MNA): a practical assessment tool for grading the nutritional state of of elderly patients. Facts and Research in Gerontology. 1994; 4: 15-59.

17. Chrisstenson L, Unosson M. Evaluation of nutritional assesment techniques in elderly people newly admitted to municipal care. Eur J Clin Nutr. 2002; 56(9): 810-8.

18. Çevik A, Basat O, Uçak S. Evde sağlık hizmeti alan yaşlı hastalarda beslenme durumunun değerlendirilmesi ve beslenme durumunun laboratuvar parametleri üzerine olan etkisi. Konuralp Tip Dergisi. 2014; 6(3): 31-7.

19. Akan H, Ayraler A, Hayran O. Evde sağlik birimine başvuran yaşlı hastaların beslenme durumları. Türk Aile Hek Derg. 2013; 17(3): 10612.

20. Akpınar P, İçağasığlu A. D Vitamininin Yaşam Kalitesi ile İlişkisi. Türk Osteoporoz Dergisi. 2012; 18: $13-8$. 